\title{
Does Vocational Guidance Become Gendered When Discussing Construction?
}

Valerie Francis and Adele Prosser (The University of Melbourne, Australia)

\begin{abstract}
The Australian construction industry is highly reliant on the local labour force and those employed within it undertake a wide variety of roles ranging from labouring to management. In the past 20 years construction has seen record levels of employment; however lack of skilled labour is becoming problematic. Australia, like most industrialised countries, has an ageing population due to falling birth rates, increased life expectancy and the ageing of the large post-World War II 'baby boom' generation. Deciding on a career is one of the most fundamental activities in a young person's life and the role of the school career counsellor is crucial in this process. This research examined secondary school career counsellor's knowledge of construction, their perceptions of it as a good career choice and how often they directed male and female students to investigate construction as a career. Comparisons using paired t-tests found career counsellors perceived construction to be a better career option for young men, and directed them more frequently than women, to explore construction careers. The findings also indicate that an educative model, where students and counsellors gain firsthand knowledge from people working in the industry, may counter negative gender stereotypes associated with this area of work and encourage more young people, both male and female, to consider a career in the construction industry.
\end{abstract}

Keywords: construction, career counsellors, workplace diversity, labour

\section{Introduction}

Construction is an essential and growing industry in Australia (Australian Bureau of Statistics [ABS] 2010). Despite the global financial crisis, skill shortages still exist within the industry (Department of Education, Employment and Workplace Relations [DEEWR], 2011). For instance, within the trades there are currently shortages of plumbers, bricklayers and cabinetmakers. Similarly, for professional and management roles there are shortages of civil and structural engineers, surveyors, construction estimators, project managers and engineer managers (DEEWR 2011). This situation is predicted to worsen as birth rates fall, life expectancy increases, and the large post-World War II baby boom generation ages and moves into retirement (Jorgensen 2004; ABS 2009). Attracting young people into construction as a long term career path is essential if the industry is to build and maintain a sustainable workforce.

Young people usually make initial career choices during secondary school, after exploring a broad range of career options (Gysbers 2008). School career counsellors provide vocational guidance to students, and can have an influential role in the decision making process. They encourage young people to explore career options, before following their chosen vocational path.

The construction industry is characterised as being male dominated and this aspect of the industry has altered little over the past twenty years in Australia (Francis 2010), despite the Sex Discrimination Act of 1984 legislating for gender equality. A stereotype exists about construction being dirty, dangerous and macho and therefore unsuitable work for females 
(Barthorpe et al. 2000). Gender socialisation from early childhood, and gender role schemas reinforce attitudes about what is appropriate work for males and females, and may contribute to the gender disparity within construction (Bem 1981; Martin and Halverson 1981; Blau et al. 2002). Career counsellors too have generally been socialised into considering construction as a more suitable career path for males than females, and therefore may not actively encourage females to explore it as a career option. With this issue in mind, the current research examined how career counsellors perceive construction as a career option, and if career counsellors recommend the exploration of construction careers to males more frequently than to females.

\section{Gender Disparity and Construction}

A review of employment in the Australian construction industry, using the most recently available census data from the ABS, confirms the gender disparity which earns the industry the reputation of being male dominated (Francis 2010). Whilst from 1986 to 2006 the number of females employed in the construction industry increased from 55,170 to 94,100, this represented only a mere $0.4 \%$ increase overall of women's participation in the industry; which rose from $12.9 \%$ in 1986 to $13.3 \%$ of the workforce in 2006 . Whilst women have made progress in managerial and professional roles, with $9.6 \%$ of all managers and $26 \%$ of all professionals being female their participation in the trades, which is by far the largest sector of employment, has been stagnant at 1.6\% for 20 years (Francis 2010).

The reasons females are underrepresented in the construction workforce are multiple and complex. Trade roles are often perceived as dangerous, and requiring physical strength and stamina, resulting in females self-selecting themselves out of the industry (Polachek 1981). Some research points to discriminatory practices influencing choice (Phelps 1972; Williams and Kenison 1996; Dainty and Lingard 2006) and other research suggest that women make occupational choices based on perceived risks. Grazier and Sloane (2008) found that women, and in particular mothers and sole parents, selected roles which had less risk and were safer. Although physical strength is still of importance in many trade roles, this has become of less importance than in previous times due to more stringent $\mathrm{OH} \& \mathrm{~S}$ requirements. Management and professional roles in construction are often perceived to require strong backgrounds in mathematics and science. Worryingly there is a trend in Australia and the United Kingdom for females to choose not to study these subjects at school as they believe from an early age that they are not as competent as males. Females can therefore self-select themselves out of the possibility of white collar professional construction roles later on in life (Fielden et al. 2000), despite academic results showing that females perform equally well as males in these subjects (Watt 2007). Further, the traditional male work culture of long hours, including regular overtime and six day working weeks common in construction, are not supportive of work-family balance or the additional household and family responsibilities many females will shoulder in their lifetime (Francis et al. 2009; Francis et al. 2010). Part-time and regular casual work is uncommon in construction jobs and often actively discouraged by unions trying to protect current working conditions (e.g. Dabke et al. 2008; Dainty and Lingard 2006), or by employers trying to meet deadlines in a competitive job market (Barthorpe et al. 2000; Lingard and Francis 2004). In addition to all these contributing factors, perhaps the most difficult factor to identify and change is an unconscious programmed belief within society that females do not work in construction. Perhaps the statement by Hulme (2006, p. 143) when referring to industrialised trades puts it in a nutshell 'It is viewed by most people, almost without second thought, as men's work'.

Francis, V. and Prosser, A. (2012) 'Does vocational guidance becomes gendered when discussing construction?', Australasian Journal of Construction Economics and Building, Conference Series, 12 (1) 73-83 


\section{Gender Socialisation and Schemas}

Gender identity develops in early childhood, and there have been many psychological theories explaining this developmental process (e.g. Kohlberg 1966; Bem 1981; Bussey and Bandura 1999). Martin and Halverson's cognitive gender schema theory (1981) asserts that gender identity has formed by the age of three. Gender schema theory discusses the formation of gender identity as a process (Bem 1981). Information surrounding the child, including that gleaned from family, friends, school, the media and engagement with everyday life, is assimilated into the child's gender identity. Gender schema influences the choices a person makes throughout the rest of their lives, including roles, behaviour, attitudes and careers.

Traditionally vocational psychology has encouraged career decision-making based on matching an individual's abilities and interests with compatible characteristics in specific work environments (Parsons 1909; Holland 1959). However, despite this practice, children still perpetuate gendered patterns of behaviour and follow gendered careers. Gottfredson's Theory of Circumscription, Compromise and Self-Creation (1981, p.2002) explored this phenomenon and proposed that children internalise gender and class stereotypes as they grow up, through socialisation from the stimuli surrounding them. By six to eight years old, before being old enough to reason through whether or not an occupation might suit them personally, children have learned what is considered appropriate behaviour for their gender and may exclude considering themselves for particular occupations based on their gender schemas.

By adolescence young people categorise career information along three dimensions; gender (masculine/feminine), level of prestige, and area of work. Young people make career choices based on how they perceive occupations according to these categories, and whether their categorisation fits with their personal self-image. Gottfredson (1981, p. 2002) also theorises that females often eliminate potential career paths prematurely based on gender stereotypes, and therefore do not allow themselves the opportunity to pursue their highest career aspirations.

While gender socialisation and each young person's own internalised gender schema impact on the career path chosen and pursued (Blau et al. 2002), recent studies with young people in the United Kingdom and Australia have found that parents, teachers and career counsellors were all significant contributors to the final career decisions made (Kniveton 2004; Bright et al. 2005). These individuals have also been socialised themselves into believing construction is a more suitable career path for males than females, and therefore may not actively encourage females to explore this career option.

\section{The Role of the School Career Counsellor}

Young people usually make initial career choices during secondary school, after exploring a broad range of career options. School career counsellors provide vocational guidance to young people, and can have an influential role in the decision making process. Their role includes facilitating young people's information gathering about areas of potential interest, ensuring that a wide range of vocational alternatives are thoroughly explored, and that accurate information is gained about the many career opportunities available to each young person, including within the construction industry (Gati and Tal 2008). The career decisionmaking process can be aided by career counsellors who facilitate this process for secondary school students. Gati and Asher's (2001) career decision-making model outline three critical stages - the pre-screening, in-depth exploration and choice. The pre-screening involves identifying a number of viable alternatives from a range of occupations known to the individual. The next stage includes the in-depth exploration of these alternatives involving

Francis, V. and Prosser, A. (2012) 'Does vocational guidance becomes gendered when discussing construction?', Australasian Journal of Construction Economics and Building, Conference Series, 12 (1) 73-83 
consideration as to the suitability of the role. This consideration is two-way and involves both the student judging their own suitability to the job as well as their ability to comply with the requirements of the role (e.g. additional education, physical strength etc.). In the last stage a comparison of the alternatives would be made before the choice of the most suitable alternative. It is clear from this model that the quality of the choice made is highly dependent on the first two stages, however of primary importance is the first stage. If alternatives are not identified there, or discarded based on false information, then this severely compromises the process. The role of the career counsellor, in bringing attention to alternatives which the student may not be aware of, and/or providing accurate information to correct other information the student may have misinterpreted, is crucial.

However, while career counsellors try to support impartial, informed decisionmaking, encouraging a realistic and good fit between the individual and their career choice, Gottfredson (1981, p.2002) suggests that this goal is virtually impossible. When career decisions are being made, it is from the framework of self-concepts and images of occupations, including gender appropriateness, already internalised by the young person and by the career counsellor to seem normal.

\section{Research Aims and Hypotheses}

This research investigated whether school career counsellors' perceptions of construction were of an industry which provided equally good career options for young men and young women, or whether there were gender biases in operation. The amount of experience the career counsellor had in their role, the impact of personally knowing someone working in construction, and self-rated knowledge of careers in construction compared with other careers, were all examined to understand the possible dynamics impacting on career advice. Based on past research into gender schemas (Bem 1981; Martin and Halverson 1981) and socialisation (Gottfredson 1981, p.2002), it was hypothesised that: (1) career counsellors would consider construction a better choice for young men than young women, and (2) career counsellors would refer young men more regularly to construction careers than young women.

\section{Method}

\section{Procedure}

Participants were recruited at Australian Careers Service (ACS) seminars held in the Eastern States of Australia during late 2010. Free annual seminars are held by the ACS as a professional development opportunity for career counsellors and advisors to access up-to-date information about a broad range of industries (Hobsons 2011). The ACS agreed to distribute questionnaires before each construction focused career information presentation. The anonymous questionnaire was distributed, completed and collected before the information sessions commenced. The questionnaire took approximately five minutes to complete.

\section{Participants}

Questionnaires were returned by 121 secondary school career counsellors of whom 83 were female (69.2\%) and 37 were male (30.6\%). Sixty-two participants worked full-time (51.2\%) and a further 59 participants worked part-time $(48.8 \%)$ in their career counselling roles. Work environments were mainly co-educational (90.1\%), but seven of the career counsellors were

Francis, V. and Prosser, A. (2012) 'Does vocational guidance becomes gendered when discussing construction?', Australasian Journal of Construction Economics and Building, Conference Series, 12 (1) 73-83 
employed in girls-only schools (5.8\%) and five of the career counsellors were employed in boys-only schools (4.1\%). Participants reported experience working in their current career counselling roles with the mode being 2 to 5 years (46 participants with some experience), with 21 having a year or less experience (limited experience), 22 having 6 to 10 years' experience (moderate experience) and 27 having greater than 10 years' experience (very experienced).

\section{The questionnaire}

A brief questionnaire was developed for ease of completion by participants in a limited time in a public setting. Five questions addressed demographic information and asked about experience in role, gender, student population's gender, working full-time or part-time, and if participants personally knew someone in the construction industry (No $=0$ and Yes $=1$ ). Participants were asked to rate their knowledge of construction careers, in comparison with other careers, on a 5 -point Likert scale, where $1=$ very poor knowledge and $5=$ very good knowledge. The final four questions identified participants' attitudes and actions in relation to promoting the construction industry as a favourable career option to students. Participants were asked whether they honestly believed construction offered a good career option to young men and a good career option to young women. Responses were given on 5-point Likert scale, where $1=$ very poor option and $5=$ very good option. Finally participants were asked to report how often they directed young men, and how often they directed young women into careers in construction, using 5-point Likert scales, where $1=$ never and $5=$ always. A 5-point Likert scale, rather than a 7 or 10 -point scale, was considered appropriate as it eased the pressure of decision making due to the limited response time available to the participants.

\section{Data analysis}

Data were analysed using SPSS for Windows (version 20). All variables were examined for reliability of measurement and data screening confirmed that all responses were in range. No extreme variations from normality in the skewness or kurtosis of the variables were found; therefore no transformations of the data were required (Muthén and Kaplan 1985). Descriptive statistics, including means and standard deviations, were then calculated for each variable. Bi-variate and point biserial correlation analyses were then conducted to identify any relationships between variables. Paired-samples t-tests were used to test for significant differences in career counsellors' mean scores rating construction as a good career option for young men and young women, and for the frequency with which they directed each gender to construction careers.

\section{RESULTS}

\section{Correlations}

Correlation analyses examined the linear relationships between the main study variables. The results are presented in Table 1.

The relationship between career counsellors' experience in their current role, and their self-rated knowledge of construction as a career, perceptions of construction being a good career option for young women, and reported frequency of directing young women to explore a construction career, were significantly and positively correlated. However the relationship between career counsellors' years of experience in their current role and their perceptions of

Francis, V. and Prosser, A. (2012) 'Does vocational guidance becomes gendered when discussing construction?', Australasian Journal of Construction Economics and Building, Conference Series, 12 (1) 73-83 
construction being a good career option for young men and reported action of directing young men to explore a construction career was not significant. For personal acquaintance with someone in the construction industry, the point biserial correlations were only significantly and positively correlated with career counsellors' self-rated knowledge of careers in construction, and with frequency of directing young women to a construction career.

Table 1: Means, Standard Deviations, Pearson and Point Biserial correlations for study variables

\begin{tabular}{|c|c|c|c|c|c|c|c|c|}
\hline & Mean & SD & 1 & 2 & 3 & 4 & 5 & 6 \\
\hline $\begin{array}{l}\text { 1. Experience in } \\
\text { current role }\end{array}$ & 2.47 & 1.04 & 1 & & & & & \\
\hline $\begin{array}{l}\text { 2. Personally know } \\
\text { someone in } \\
\text { construction } \neq\end{array}$ & 0.85 & - & .052 & 1 & & & & \\
\hline $\begin{array}{l}\text { 3. Self-rated } \\
\text { knowledge of } \\
\text { construction industry }\end{array}$ & 3.55 & 0.75 & $\begin{array}{l}.242 * \\
*\end{array}$ & $\begin{array}{l}.256 * \\
*\end{array}$ & 1 & & & \\
\hline $\begin{array}{l}\text { 4. Good career option } \\
\text { for young men }\end{array}$ & 4.46 & 0.54 & .146 & $.233 *$ & $\begin{array}{l}.266^{*} \\
*\end{array}$ & 1 & & \\
\hline $\begin{array}{l}\text { 5. Good career option } \\
\text { for young women }\end{array}$ & 3.74 & 0.89 & $.193 *$ & .174 & $\begin{array}{l}.199 * \\
*\end{array}$ & $\begin{array}{l}.401 * \\
*\end{array}$ & 1 & \\
\hline $\begin{array}{l}\text { 6. Direct young men } \\
\text { to construction career }\end{array}$ & 3.72 & 0.51 & -.032 & .055 & .149 & $\begin{array}{l}.312 * \\
*\end{array}$ & -.155 & 1 \\
\hline $\begin{array}{l}\text { 7. Direct young } \\
\text { women to } \\
\text { construction career }\end{array}$ & 2.61 & 0.76 & $.202 *$ & $\begin{array}{l}.218 * \\
*\end{array}$ & $\begin{array}{l}.269 * \\
*\end{array}$ & .166 & $\begin{array}{l}.416^{*} \\
*\end{array}$ & .190 \\
\hline
\end{tabular}

₹ correlations related to this variable are point biserial, all others correlations are pearsons product-moment.

** Correlation is significant at the 0.01 level (2-tailed).

* Correlation is significant at the 0.05 level (2-tailed).

The relationship between career counsellors' self-rated knowledge of careers in construction, and construction being perceived as a good career option for both genders, and the reported frequency with which career counsellors directed young women to construction careers, were significantly and positively correlated. The relationship between self-rated knowledge of careers in construction, and reported frequency with which career counsellors directed young men to construction careers, were not correlated. Career counsellors who perceived construction to be a good career option for young men, also perceived construction to be a good career option for young women, and more frequently directed young men to construction careers. Career counsellors who perceived construction to be a good career option for young women, also perceived construction to be a good career option for young men, and more frequently directed young women to construction careers, but not young men. Finally, the correlation between the frequency of directing young men to construction careers, and the frequency of directing young women to construction careers, was not correlated.

\section{Paired t-tests}

For the two questions asking career counsellors to rate their perceptions of construction as a good career option for young men and for young women, 121 participants responded. A

Francis, V. and Prosser, A. (2012) 'Does vocational guidance becomes gendered when discussing construction?', Australasian Journal of Construction Economics and Building, Conference Series, 12 (1) 73-83 
paired-samples t-test (two tailed) was used to determine if career counsellors' perceptions were that construction was a better career for young men than for young women. The difference between construction being considered a good career option for young men $(\mathrm{M}=$ 4.46 , $\mathrm{SD}=0.54)$, and a good career option for young women $(\mathrm{M}=3.74$, $\mathrm{SD}=0.89)$ was found to be significant, $\mathrm{t}(120)=9.43, \mathrm{p}=.000$.

For the two questions asking career counsellors' to rate their perceptions of how often they directed young men and young women to consider construction careers, 103 participants responded. There were fewer responses to these questions as some participants taught at single sex schools. A paired-samples t-test (two tailed) was conducted to determine if the career counsellors' perceptions were that they directed young men to consider construction careers more frequently than young women. The difference between directing young men into a construction career $(\mathrm{M}=3.72, \mathrm{SD}=0.51)$, and directing young women into a construction career $(\mathrm{M}=2.59, \mathrm{SD}=0.76)$ was found to be significant, t $(102)=13.91$, $\mathrm{p}$ $=.000$. Therefore this study did find gender differences supporting the two hypotheses, whereby career counsellors' reported a perception of construction being a better career option for young men than for young women, and reported directing young men into construction careers more frequently than directing young women.

\section{Discussion and Conclusion}

Career counsellors have a pivotal role in supporting young people in their exploration of career options. This research found that while career counsellors acknowledge that construction is a good career option for both young men and young women, consistent with our hypotheses, there was a perception that the industry was a better career for males, and young men were more frequently directed into construction than young women.

As may be expected, greater experience working as a career counsellor, and also personally knowing someone working in the construction industry, were both linked to a higher self-rated knowledge of construction careers, compared with other types of careers. Further, those career counsellors with more experience in their role, a higher self-rated knowledge of construction careers and a personal acquaintance in construction were more likely to direct more young women to consider a career in construction. Unexpectedly however this was not the case for young men. This knowledge and acquaintance with construction was also related in varying degrees to their perception of construction as a good career option for both young men and women. Those who reported a higher regard for construction as a career for women also reported a higher likelihood of directing women to considering construction as a career. The same was true for young men.

Career counsellors did therefore exhibit a gender bias in this study. An explanation for the gender differences found in this study stem from the theories of gender socialisation (Blau et al. 2002; Gottfredson 1981, p.2002) and internalised gender role schemas (Bem 1981; Martin and Halverson 1981). There is evidence that roles in construction are still viewed as traditional masculine career paths, more appropriate for males than females. For example, in a recent American study involving a series of experiments with primary school children aged 6-12 years old, 107 children rated 54 occupations for gender and occupational status (Teig and Susskind 2008). Similar to Bem's (1974) sex role inventory, careers could be classified masculine, feminine or neutral. This study is a reminder that children in the 21st century still perceive career roles as gendered, and construction roles as masculine. Career counsellors, despite their knowledge and training about encouraging equal opportunities for both genders in all vocational fields of endeavour (e.g. AHRC 2012), may also be similarly influenced by

Francis, V. and Prosser, A. (2012) 'Does vocational guidance becomes gendered when discussing construction?', Australasian Journal of Construction Economics and Building, Conference Series, 12 (1) 73-83 
gender role schemas when given an explicit gender choice about an industry traditionally perceived as male.

Additional unsolicited qualitative comments made by some of the career counsellors that the construction industry is sexist, reluctant to employ females, and a difficult culture for females to succeed in, may inform this apparent bias. These career counsellors' perceptions hold some credence. Females entering the construction industry still encounter an entrenched male culture, open resentment, discrimination, harassment and sexist behaviour from male colleagues (e.g. Dainty et al. 2000; Fielden et al. 2000; Dabke et al. 2008). Females are commonly socially isolated on construction sites and unable to approach or rely on senior male colleagues for support (Dainty et al. 2000).

As noted earlier a traditional male work culture of full-time work, long hours, weekend work, and projects undertaken in geographically different locations makes meeting family responsibilities challenging (Fielden et al. 2000; Dainty and Lingard 2006; Menches and Abraham 2007; Dabke et al. 2008; Francis et al. 2010). Alternative work practices are not understood or encouraged by management, owners or unions within the industry (Dainty and Lingard 2006; Dabke et al. 2008; Francis et al. 2010) and in doing so the industry is effectively limiting recruitment to half the potential workforce. Without greater gender diversity, the construction industry risks perpetuating a traditional male work culture indefinitely.

Gadassi and Gati (2009) encourage career counsellors to elicit preferences for careerrelated aspects of occupations when working with young people, rather than asking about specific careers they may like to pursue. By focusing on the aspects of work enjoyed by the young person, there is less likelihood that career choices will be gender stereotyped, and a broader range of occupations can be considered, based on abilities and interests instead of internalised gender role schemas.

The most important findings to emerge from this research was that personally knowing someone in construction increased the likelihood that the career counsellors would encourage young women to consider construction as a career. Whilst this did not hold true for young men this personal acquaintance also increased the perceptions of construction as being a good career option for young men. Greater knowledge of construction was associated with a greater regard for construction as a career for young men and with directing young men and women to consider construction. Proactive policiesto improve links between school and industry are therefore very important for recruitment from both genders. Strategies such as holding information sessions in schools with "chat with a tradey" and "chat with an engineer or project manager" sessions could provide counsellors and students with immediate access to relevant information about construction careers. School curriculums that also include educational site visits, and collaborative learning where building projects at or near schools are used as a resource incorporated into practical mathematics, science and management subjects at primary and secondary school levels could break down some of the barriers and misconceptions that exist about working in the construction industry.

With skill shortages an on-going issue for construction in Australia, attracting young people, regardless of gender, into the industry as a long term career path is essential if the construction industry is to build and maintain a sustainable workforce throughout the 21st century. Combating internalised gender role schemas is very challenging. However these findings indicate that an educative model, whereby young people, parents and career counsellors are able to access current information about construction first-hand from people working in the industry, may counter negative gender stereotypes associated with this area of

Francis, V. and Prosser, A. (2012) 'Does vocational guidance becomes gendered when discussing construction?', Australasian Journal of Construction Economics and Building, Conference Series, 12 (1) 73-83 
work and encourage more young people, both male and female, to consider a career in the construction industry.

\section{Limitations of the study}

The current cross-sectional and preliminary research into an area not previously explored, was conducted in a very limited timeframe, which reduced the number of questions asked. The career counsellors participating in this research were voluntarily attending information sessions addressing careers in construction making them a highly motivated convenience sample which may not be representative.

\section{References}

Australian Bureau of Statistics (2009). Future population growth and ageing (Cat. No. 4102.0), Australian Government Printing Service, Canberra.

Australian Bureau of Statistics (2010). Australian Economic Indicators, October 2010 (Cat. No. 1350.0), Australian Government Printing Service, Canberra.

Australian Human Rights Commission (2012). Sex Discrimination. Canberra, retrieved from www.humanrights.gov.au/sex_discrimination/index.html, < March 2, 2012>

Barthorpe, S., Duncan, R., and Miller, C. (2000). 'The pluralistic facets of culture and its impact on construction.’ Property Management, 18, 335-351.

Bem, S.L. (1974). 'The measurement of psychological androgyny.' Journal of Consulting and Clinical Psychology, 45, 155-162.

Bem, S.L. (1981). 'Gender schema theory: A cognitive account of sex-typing.' Psychological Review, 88, 354-364.

Blau, F.D., Ferber, M.A., and Winkler, A.E. (2002). The economics of women, men, and work, Prentice-Hall, New Jersey.

Bright, J.E.H., Pryor R.G.L., Wilkenfeld, S., and Earl, J. (2005). 'The role of social context and serendipitous events in career decision making.' International Journal for Educational and Vocational Guidance, 5, 19-36.

Bussey, K. and Bandura, A. (1999). 'Social cognitive theory of gender development and differentiation.’ Psychological Review, 106, 676-713.

Dabke, S., Salem, O., Genaidy, A. and Daraiseh, N. (2008). 'Job satisfaction of women in construction trades.' Journal of Construction Engineering and Management, 134, 205216.

Dainty, A.R.J. and Lingard, H. (2006). 'Indirect discrimination in construction organizations and the impact on women's careers.' Journal of Management in Engineering, 22, 108118.

Dainty, A.R.J., Neale, R.H. and Bagilhole, B.M. (2000). ‘Comparison of men’s and women’s careers in UK construction industry.' Journal of Professional Issues in Engineering Education and Practice, 126, 110-115.

Department of Education, Employment and Workplace Relations (2011). Skill Shortages in the Construction Industry, June 2011, Canberra, retrieved from: 
http://www.deewr.gov.au/Employment/LMI/SkillShortages/Documents/SkillShortages_C onstructionInd.pdf , < June 20 2011>

Fielden, S., Davidson, M., Gale, A., and Davey, C. (2000). 'Women in construction: the untapped resource.' Construction Management \& Economics, 18, 113-121.

Francis, V. (2010). 'A twenty year review of women's participation within the construction trade sector of the Australian construction industry.' Proc., the RICS Foundation Construction and Building Research Conference, COBRA, London, England, ISBN: 9781842196199, retrieved from: http://www.rics.org/site/ download_feed.aspx?fileID=8094\&fileExtension=PDF,< March 2 2012>

Francis, V., Fulu, E. and Lingard, H. (2009). Is it a problem? in Managing Work-Life Balance in Construction, eds. H. Lingard \&V. Francis, Spon Press, Abingdon, Oxon, pp. 1-37.

Francis, V., Lingard, H., and Turner, M. (2010). 'Work-family experiences of blue and white collar workers in the Australian construction industry.' Proc., the RICS Foundation Construction and Building Research Conference, COBRA, London, England, ISBN: 9781842196199, retrieved from: http://www.rics.org/site/download_ feed.aspx?fileID=7899\&fileExtension=PDF, <March 2 2012>

Gadassi, R. and Gati, I. (2009). 'The effect of gender stereotypes on explicit and implicit career preferences.' The Counseling Psychologist, 37, 902-922.

Gati, I. and Asher, I. (2001). 'The PIC model for career decision making: Prescreening, indepth exploration, and choice', in Contemporary models in vocational psychology: A volume in honor of Samuel H. Osipow, eds. T. L. Leong and A. Barak, Lawrence Erlbaum Associates, New Jersey, pp. 7-54.

Gati, I., and Tal, S. (2008). 'Decision-making models and career guidance.' In International Handbook of Career Guidance, eds. J. A. Athanasou \& R. Van Esbroeck, Springer Science \& Business Media B.V., New York, pp. 157-185.

Gottfredson, L.S. (1981). 'Circumscription and compromise: A developmental theory of occupational aspirations.' Journal of Counseling Psychology Monograph, 28, 545-579.

Gottfredson, L.S. (2002). 'Gottfredson's theory of circumscription, compromise, and selfcreation', in Career choice and development, $4^{\text {th }}$ edn., ed. D. Brown, Jossey-Bass, San Francisco, pp. 85-148.

Grazier, S., and Sloane, P. J. (2008). 'Accident risk, gender, family status and occupational choice in the UK.' Labour Economics, 15, 938-957.

Gysbers, N. C. (2008). 'Career guidance and counselling in primary and secondary educational settings', in International Handbook of Career Guidance, eds., J. A. Athanasou \& R. Van Esbroeck, Springer Science \& Business Media B.V, New York, pp. 249-263.

Hobsons Australia (2011). The Good universities guide 2011. Melbourne, retrieved from http://www.gooduniguide.com.au/Australian-Careers-Service/2011-ACS-Seminars, <September 12 2011>

Holland, J.L. (1959). 'A theory of vocational choice.' Journal of Counseling Psychology, 6, 35-45.

Hulme, K. (2006). 'Making the Shift from Pink Collars to Blue Ones; Women's NonTraditional Occupations.’ Labour/Le Travad, 57 (Spring), 143-65.

Francis, V. and Prosser, A. (2012) 'Does vocational guidance becomes gendered when discussing construction?', Australasian Journal of Construction Economics and Building, Conference Series, 12 (1) 73-83 
Jorgensen, B. (2004). The Ageing Population: Implications for the Australian Workforce, Hudson, Global Resources \& Human Capital Solutions, Sydney.

Kniveton, B.H. (2004). 'The influences and motivations on which students base their choice of career.' Research in Education, 72, 47-59.

Kohlberg, L. (1966). 'A cognitive-developmental analysis of children's sex-role concepts and attitudes', in The development of sex differences, ed. E. E. Maccoby, Stanford University Press, Stanford, pp.82-173.

Lingard, H. and Francis, V. (2004). 'The work-life experiences of office and site-based employees in the Australian construction industry.' Construction Management and Economics, 22, 991-1002.

Martin, C. L. and Halverson, C.F. (1981). 'A schematic processing model of sex typing and stereotyping in children.’ Child Development, 52, 1119-1134.

Menches, C.L. and Abraham, D.M. (2007). 'Women in construction - Tapping the untapped resource to meet future demands.' Journal of Construction Engineering and Management, 133, 701-707.

Muthén, B., and Kaplan, D. (1985). 'A comparison of some methodologies for the factor analysis of non-normal Likert variables.' British Journal of Mathematical and Statistical Psychology, 38, 171-189.

Parsons, F. (1909). Choosing a vocation, Houghton-Mifflin, Boston.

Phelps, E. (1972). 'The statistical theory of racism and sexism.' American Economic Review, 62, 659-661.

Polachek, S. W. (1981). 'Occupational self-selection: a human capital approach to sex differences in occupational structure.' Review of Economics and Statistics, 63, 60-69.

Teig, S. and Susskind, J. E. (2008). 'Truck driver or nurse? The impact of gender roles and occupational status on children's occupational preferences.' Sex Roles, 58, 848-863.

Watt, H.M.G. (2007). 'A trickle from the pipeline: Why girls under-participate in maths.' Professional Educator, 6, 36-41.

Williams, R.M. and Kenison, R.E. (1996). 'The way we were? Discrimination, competition, and inter-industry wage differentials in 1970.' Review of Radical Political Economics, 28, $1-32$. 